\title{
Organizational Citizenship Behavior on Retail Employees
}

\author{
Benedicta Dinda Christia Hernani ${ }^{\bowtie}$, Palupiningdyah
}

Management Department, Faculty of Economics, Universitas Negeri Semarang, Semarang, Indonesia

\section{Article Information}

Article History:

Received January 2020

Approved February 2020

Published March 2020

\section{Keywords:}

Perceived Organizational

Support, Extraversion personality, Affective Commitment, Organizational Citizenship Behavior.

\begin{abstract}
The purpose of this study was to determine the direct and indirect influence POS and extraversion personality to OCB and affective commitment as mediation. The population in this research that all employees Aneka Jaya Supermarket Sambiroto number of 126 employees. Mechanical sampling using saturated sample so that the entire population of the research sample. Methods of data collection using a questionnaire with a Likert scale of 1-5. Data analysis method is test instrument (validity and reliability), a descriptive analysis of the respondents, and test hypotheses and test path analysis with the data processing program SPSS version 25 . The results showed that all hypothesis is accepted. Therefore, the POS has positive and significant effect on affective commitment. Extraversion personality has positive and significant effect on affective commitment. Affective commitment has positive and significant effect on OCB. POS has positive and significant impact on OCB. Extraversion personality has positive and significant effect on OCB. The test results of path analysis also showed that the POS and extraversion personality and sgnifkan positive effect on OCB through affective commitment. POS positive and significant impact on OCB. Extraversion personality positive and significant impact on OCB. The test results of path analysis also showed that the POS and extraversion personality and sgnifkan positive effect on OCB through affective commitment. POS positive and significant impact on OCB. Extraversion personality positive and significant impact on OCB. The test results of path analysis also showed that POS and extraversion personality and sgnifkan positive effect on OCB through affective commitment.
\end{abstract}

\section{INTRODUCTION}

Increasingly rapid development period requires the organization to adapt and find the right strategies in order to face the challenges (Oussama \& Johari, 2016). Development of human resources is very important to do (Udiyana et al., 2015). Besides maintaining employee has a company that employees feel is also very important (Tahapary \& Martono, 2017). One of the global strategic issues in human resource management are a growing concern is the extra role behaviors that one of them is organizational citizenship behavior or OCB (Mukhodah \& Ranihusna, 2018). OCB is associated with positive antecedents and consequences (Bolino, Klotz, Turnley, \& Harvey, 2013). OCB carried out by employees can be derived from different sources (Bolino et. al., 2013). OCB is an individual contribution that exceeds the demands of the role in the workplace (Fitriastuti, 2013). According to Afsar and Badir (2016) when organizations try to foster a sense of OCB on the employee, the employee will perceive that the office becomes a more attractive place to work and organization can recruit, train and retain the best people. So it is important for organizations to try to bring up the OCB on the employee.

In the service industry, employees are required in order to show the OCB in the workplace (Chiang \& Hsieh, 2012). OCB is an attitude that

(C) 2019 Universitas Negeri Semarang

\footnotetext{
Correspondence Address:

L2 Building, 1st Floor, Faculty of Economics, Universitas Negeri Semarang

Jalan Taman Siswa, Sekaran, Gunungpati, Semarang, 50229

E-mail: bdindaach@gmail.com
} 
so many organizations are expected to have its employees (Aussy \& Sudarma, 2017).

Organizations that want employees to OCB should focus primarily on the support of the organization is perceived by employees (Afsar $\&$ Badir, 2016). According to the theory of organizational support, perceived organizational support should emberikan reciprocity that leads to an obligation to help organizations (Kurtessis et al., 2016). Based on previous studies, organizational citizenship behavior is one factor that gives the advantage to the organization (Podsakoff et al., 2009; Somech \& Zahavy, 2013; Knippenberg et al., 2015; Dai et al., 2016). That is because the organizational citizenship behavior can improve organizational performance (Turnipseed \& Rassuli, 2005).

One forming organizational citizenship behavior of employees is perceived organizational support (Ardi \& Sudarma, 2015). Support the organization held by employees will encourage employees to do the organizational citizenship behavior (Novira \& Martono, 2015). According to Krishnan and Mary (2012) perceived organizational support is the belief of employees that the organization concerned and to appreciate the contributions of the employees in the long term for the success of the organization.

Organizational citizenship behavior is also always associated with individual behavior (Hoon \& Tan, 2008). The human personality is made up of many components or properties (Nurlaila \& Sudarma, 2017). Every employee has a different personality, so as to form the pattern of employee behavior is different also. The dimensions of personality has a positive relationship with the deeper aspects of the organizational citizenship behavior (Organ \& Ling1, 1995). So the personality is the one of factors that influence organizational citizenship behavior (Mahdiuon et al., 2010).

Based on research previous on OCB, there are several variables that affect the appearance of organizational citizenship behavior are organizational commitment (Feather \& Rauter, 2004; Pradhan \& Jena, 2016), Perceived organizational support (Ahmed et al., 2015; Afsar \& Badir, 2016), Organizational Justice (Chan \& La, 2016; Lim \& Loosemore, 2017) and personality type (Mosalaei et al., 2014; Revelle, 2016; Murphy et al., 2017). So in this study focuses on perceived organizational support, personality type (focused on extraversion personality) and organizational commitment (especially affective commitment).

There are differences in the results of the research on the impact of the perceived organizational support with organizational citizenship behavior. According to Gupta et al. (2016) perceived organizational support was significantly related to organizational citizenship behavior. However, the research conducted by Mangundjaya (2012) showed that no significant difference between the perceived organizational support with organizational citizenship behavior.

In addition, research on the effect of extraversion personality with organizational citizenship behavior there is a research gap. According to Judge et al. (2014) extraversion personality types have a significant impact on organizational citizenship behavior. However, the research conducted by Mosalaei et. al., (2014) showed that there was no significant effect on the extraversion personality types to organizational citizenship behavior.

Affective commitment role as mediating variables influence the perceived of the relationship of the organization support organizational citizenship behavior and relationships influence extraversion personality on organizational citizenship behavior. As research has been done by Gupta et. al., (2016) that affective commitment is able to mediate the relationship between perceived organizational support with organizational citizenship behavior. In addition, research Purba et al. (2014) revealed that affective commitment is able to mediate the extraversion personality types relationship with organizational citizenship behavior.

Research was conducted on Supermarket Aneka Jaya Sambiroto employees. Supermarket Aneka Jaya Sambiroto is one of the retail stores in the city of Semarang. Based on the observation and study pre researchers who have done the 20 employees it is obtained that the management of the store already do support organizations such as the one training that can improve the ability of employees. But apparently there are still concerns about organizational citizenship behavior.

This research is interesting to do because there is no research on organizational citizenship behavior of employees who use a retail store as a research object. In addition, research is also interesting to do because some of the variables used in this study focuses on one dimension that has always been the strongest predictor in the study of organizational citizenship behavior.

\section{Hypotheses Development}

According to Martono and Putri (2018) POS is a global trust the employees about the extent to which an organization concerned with the welfare of employees and the contributions of employees. Perceived organizational support has also been defined as the belief of employees 
to the extent to which the organization contributions of employees and give attention to the welfare of employees (Zheng, 2018). A meta-analysis showed that the perceived of organizational support plays a positive role in affective commitment of employees (Meyer et al., 2002). In the social exchange theory, the employee will repay what they received (support organizations) with a commitment to the organization (Muhammad, 2014). Which was developed especially its commitment to the employee's emotional bond with the organization (Grant et al., 2008).

Based on research conducted by Griffin et al. (2001) states that perceived support is positively related to affective commitment of employees. So it can be assumed that if an employee finds support organization then it can bring the employee affective commitment. From the above it can be formulated hypotheses as follows:

$\mathrm{H} 1$ : Perceived organizational support has positive and significant effect on affective commitment.

Personality is the dynamic characteristics of an individual and organized that affect cognition, motivation, and behavior (Ramdhani, 2007). Extraversion personality refers to the extent to which individuals self-confident, assertive and energized (Barrick \& Mount, 2005). In some studies show the results that extraversion personality associated with affective identification of individuals (Purba et al., 2014).

According to Brown (1996) emotionally stable individuals tend to experience positive feelings that can increase the positive experience of employees in the organization so it can increase employee affective commitment. So it can be assumed that extraversion personality types can bring affective commitment on the employee. From the above it can be formulated hypotheses as follows:

H2: Extraversion personality has positive and significant effect on affective commitment.

OCB is considered as a system of cooperation and the willingness of employees to contribute to the success of the organization's goals (Hidayah, 2018). According to Allen and Meyer (1990) organizational commitment is defined as the emotional attachment, identification, and the individual's involvement with the organization and the desire to survive in the organization. So the commitment the organization has an important role in the OCB (Sena, 2011).

Research has been done by Feather and Rauter (2004) shows that affective commitment has a positive relationship to organizational citizenship behavior. Affective commitment has the most dominant element in shaping the major determinant of employee behavior (Meyer et al., 2002). Employees who have a high affective commitment can identify the organization and continue to work to achieve organizational goals. From the above it can be formulated hypotheses as follows:

H3: Affective commitment has positive and significant effect on organizational citizenship behavior.

According to Afsar and Badir (2016) perceived of organizational support has been found to have an important influence on employee performance and reward of support, respect, and the relationship between employee and employer. Perceived organizational support plays an important role in the social exchange relationship between the employee and the organization (Knippenberg et al., 2013).

Perceived organizational support and emotional response to social needs that are important to employees taking into account the aspirations and values (Muhammad, 2014). When an organization providing support to employees according to their perceived, then employees are more loyal and confident and results of organizational performance will be improved, especially the role of extra role (Nisar et al., 2014). From the above it can be formulated hypotheses as follows:

$\mathrm{H} 4$ : Perceived organizational has positive and significant effect on organizational citizenship behavior.

According to the Organ (1990) individual differences play an important role in predicting whether the employee will demonstrate organizational citizenship behavior (Elanain, 2007). Employees who have a high score in extraversion personality generally outgoing, assertive, active, courageous, energetic, and eskpresif (Goldberg, 1992). So that employees with high extraversion scores will make it easier to show the organizational citizenship behavior (Elanain, 2007). From the above it can be formulated hypotheses as follows:

H5: Extraversion personality has positive and significant effect on organizational citizenship behavior.

One of the determining factors of organizational citizenship behavior is perceived organizational support (Ardi \& Sudarma, 2015). As employees' perceived organizational concerns regarding performance evaluation and employee contributions foster positive attitudes and beha- 
vior (Gupta et. al., 2016). In the study conducted by Gong and Chang (2008) have found results that when organizations provide career advancement opportunities. The employee responds with a high commitment to the organization, the performance of the company, and OCB.

According to Meyer et al. (2002) organizational support provided can increase organizational commitment. Affective commitment become a key determinant in the emergence of organizational citizenship behavior (Meyer et al., 2002; Harrison et al., 2006). So it can be assumed that there are significant indirect relationships. From the above it can be formulated hypotheses as follows: H6: Perceived organizational support has positive and significant effect on organizational citizenship behavior through affective commitment.

According to Panaccio and Vandenberghe (2012) personality is the deciding factor in the behavior of individuals in the workplace. Extraversion personality become the strongest predictors of behavior and consistent bersosial effect on organizational citizenship behavior (Purba et. al., 2014). A positive attitude shown by the employees have extraversion personality will influence the affective commitment of employees (Panaccio \& Vandenberghe, 2012).

According to Purba et al., (2014) individuals with high scores in extraversion personality will have a more stable emotions and to increase affective commitment that can ultimately lead peningkatakan organizational citizenship behavior. From the above it can be formulated hypotheses as follows:

H7: Extraversion personality has positive and significant effect on organizational citizenship behavior through affective commitment.

Based on the description of the development of the above hypothesis, the research model can be described as follows:

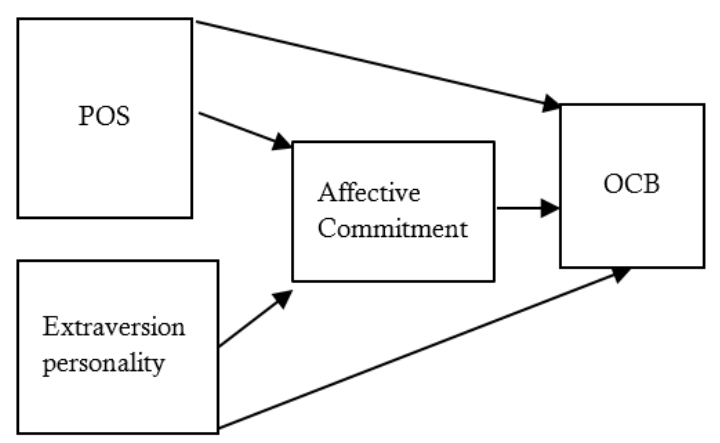

Figure 1. Research Model

\section{METHOD}

The population in this study are employees Aneka Jaya Supermarket Sambiroto of $126 \mathrm{emp}-$ loyees. The sampling technique using saturated sample so that the whole population is used as a sample. Methods of data collection using a questionnaire with a Likert scale of 1-5. The data analysis using descriptive analysis, hypothesis testing, and test path analysis using the data processing program SPSS version 25 . The instrument used in this study have been tested for validity and reliability.

This study uses a variable perceived organizational support and extraversion personality as independent variables. Organizational citizenship behavior as the dependent variable and affective commitment is used as a mediating variable.

Variable perceived organizational support was measured with 6 items belong statement (Afsar \& Badir, 2016). Examples of items that statement is "every time I got in trouble, the organization in which I work provides troubleshooting help". Extraversion personality variables were measured with the 12 item belongs statement (Mccrae et al., 2005). Examples of items that statement is "I can say unequivocally would be something I do not like".

Variable affective commitment was measured with 8 items belonging statement Allen and Meyer (1990). Examples of items that statement is "I feel the problem is the organization's my problem too". Variable organizational citizenship behavior was measured with 10 items belong statement Chiang and Hsieh (2012). Examples of items that statement is "I help my colleagues who have voluntarily excessive workload".

\section{Validity Test}

According Ghozali (2013) test is used to measure the validity of a legitimate or valid whether or not a questionnaire. A questionnaire is said to be valid if the statement on the questionnaire can reveal something that will be measured by the questionnaire (Ghozali, 2013). A statement items or questions in the questionnaire considered valid if $r$ count $>r$ table.

In this study, the number of respondents who used the validity of the test by 30 respondents, so this study is $0,361 \mathrm{r}$ table using a significance level of $5 \%$. Test the validity processed using the data processing program SPSS version 25 . There are 36 items in the test statement in this study, namely, variable perceived organizational support consisting of 6 items statement, extraversion personality variable declaration consists of 12 items, the variable affective commitment consist of 8 items 
statement and variable organizational citizenship behavior of 10 items of the statement.

Validity test results on the perceived of organizational support variable showed that 6 statement items have a value of $r$ count $>r$ table. So it can be said that all the items statement declared valid perceived organizational support and can be used on subsequent data retrieval. In the test the validity of extraversion personality variables showed that 12 items have a value statement $r$ count $>\mathrm{r}$ table. So it can be said that all the items in extraversion personality statement declared valid and can be used on subsequent data retrieval.

Validity test results on variable affective commitment shows that 8 statement items have a value of $r$ count $>r$ table. So it can be said that all items affective commitment statement declared valid and can be used on subsequent data retrieval. On the validity of the test variable organizational citizenship behavior showed that 10 items of the statement has a value of $r$ count $>r$ table. So it can be said that all organizational citizenship behavior statement item is valid and can be used on subsequent data retrieval.

\section{Reliability Test}

Reliability test is used to measure the reliability of a questionnaire. According Ghozali (2013) questionnaire can be declared reliable or reliably if someone answers on the statement is consistent or stable over time. An instrument is declared reliable if had Cronbach Alpha $(\alpha)>$ 0.70 . This study uses the data processing program SPSS version 25 to test the reliability.

Based on the results of SPSS output shows that the Cronbach Alpha value for the variable perceived of organizational support at $0.828>0.70$, Cronbach Alpha value extraversion personality variable of $0.831>0.70$, Cronbach Alpha value variable affective commitment amounted to 0.815> 0.70 , and the value of Cronbach Alpha variable organizational citizenship behavior amounted to $0.757>0.70$. It can be concluded that all the variables in this study had a Cronbach Alpha values greater than 0.70 . That is, the variable perceived of organizational support, extraversion personality, affective commitment, and organizational citizenship behavior said to be reliable.

\section{RESULT AND DISCUSSION}

\section{Descriptive Analysis}

According to Ferdinand (2014) descriptive analysis is used to provide a picture or description of empirical data collected in the study. This study uses a Likert scale of 1-5 with 1 minimum valuati- on techniques and a maximum of 5 . The analysis is performed using an index value of each indicator to describe the respondents' perceiveds of the items proposed statement (Ferdinand, 2014). This analysis was conducted to determine the general perception of respondents regarding the variables studied. Based on the research that has been done, the analysis results obtained in the description in Table 1.

Table 1. Descriptive Analysis Results

\begin{tabular}{llcl}
\hline No. & variables & Index & Criteria \\
\hline 1 & $\begin{array}{l}\text { Perceived Organiza- } \\
\text { tional Support }\end{array}$ & 76.88 & High \\
2 & $\begin{array}{l}\text { extraversion } \\
\text { personality } \\
3\end{array}$ & 81.28 & High \\
& $\begin{array}{l}\text { Affective } \\
\text { commitment }\end{array}$ & 76.06 & High \\
4 & OCB & 82.55 & High \\
\hline
\end{tabular}

Based on the results of the analysis, it can be seen that all variables in this study included in the high category. It shows that the respondents in this study considers that the management of the store is to support the organization so that employees are easier to demonstrate OCB.

\section{Hypothesis Test}

According to Ghozali (2013) the statistical test $t$ is used to show how far the influence of one explanatory variable (independent) individually in explaining the dependent variable (dependent). In this study using a data processing program that is SPSS version 25 by using a significance level of $0.05(\alpha=5 \%)$. Determination of acceptance of the hypothesis that is, if the value of sig. count $<$ sig. table then $\mathrm{HO}$ is rejected and $\mathrm{Ha}$ is accepted. While the determination of the acceptance of mediation effects is seen by comparing the value of direct influence and the total path coefficient (Ghozali, 2013). Based on the research data obtained from the questionnaire, the hypothesis test results are obtained in table 2 .

Table 2. T Statistic

\begin{tabular}{llll}
\hline Variabel & & KA & PK \\
\hline PD & T & 2,354 & 3,191 \\
& Sig. & 0,020 & 0,001 \\
KE & T & 3,179 & 5,668 \\
& Sig. & 0,002 & 0,000 \\
KA & T & - & 2,716 \\
& Sig. & - & 0,008 \\
\hline
\end{tabular}




\section{Hypothesis test 1}

In testing hypothesis 1 that is the effect of the perceived organizational support for affective commitment, the value of $t$ arithmetic is 2.354> $t$ table 1.974 with a significance level of 0.020 $<0.05$, then $\mathrm{H} 1$ which states the perceived organizational support has a positive and significant effect on affective commitment is accepted. The direction of a positive relationship indicates that when employees 'perceived organizational support are positive it will lead to employee affective commitment, and vice versa when employees' perceived organizational support are negative, employees will not have an affective commitment to the organization. The results of the study are in line with research conducted by Gupta et al., (2016) namely the perceived organizational support has a positive relationship with affective commitment.

\section{Hypothesis test 2}

In testing hypothesis 2 , that is the effect of extraversion personality on affective commitment, the result of $t$ value is $3.179>t$ table 1.974 with a significance level of $0.002<0.05$, then $\mathrm{H} 2$ which states that extraversion personality has a positive and significant effect on affective commitment is accepted. The direction of a positive relationship shows that employees with high score extraversion personalities are more likely to have affective commitments, and vice versa if employees have extraversion personality with low scores, it is difficult to have affective commitments. The results of this study are supported by research conducted by Panaccio and Vandenberghe (2012), which is that the type of extraversion personality has a positive relationship with affective commitment.

\section{Hypothesis test 3}

The statistical test $t$ on hypothesis 3 is the effect of affective commitment on organizational citizenship behavior has obtained the $t$ value of $2.716>$ $\mathrm{t}$ table 1.974 with a significance level of $0.008<0.05$, then $\mathrm{H} 3$ which states affective commitment has a positive and significant effect on organizational citizenship behavior be accepted. The positive direction of the relationship shows that when employees have affective commitment, they can easily show organizational citizenship behavior, and vice versa when employees do not have affective commitment, employees will not show organizational citizenship behavior. The results of this study are supported by research conducted by Huang et al. (2012) namely affective commitment can improve organizational citizenship behavior.

\section{Hypothesis test 4}

The statistical test $t$ on $\mathrm{H} 4$ is the effect of the perceived organizational support on organizational citizenship behavior has obtained the value of $t$ arithmetic of 3.191>t table 1.974 with a significance level of $0.002<0.05$, then $\mathrm{H} 4$ which states the perceived organizational support has a positive and significant effect on citizenship behavior organizationally accepted. A positive relationship indicates that positive employee perceived organizational support will encourage employees to exhibit organizational citizenship behavior, and vice versa when employees have negative perceiveds then employees will not exhibit organizational citizenship behavior. The results of the study are in line with research conducted by Afsar and Badir (2016) and Oussama and Johari (2016), namely the perceived organizational support has a positive and significant influence on organizational citizenship behavior.

\section{Hypothesis test 5}

In testing hypothesis 5 that the effect of extraversion personality on organizational citizenship behavior has obtained the value of $t$ count 5.668> t table 1.974 with a significance level of $0.000<0.05$, then $\mathrm{H} 5$ which states that extraversion personality has a positive and significant effect on organizational citizenship behavior is accepted. The direction of a positive relationship indicates that when employees have a high score extraversion personality it is easier to show organizational citizenship behavior, and vice versa when employees have a low score extraversion personality then it will be difficult to show organizational citizenship behavior. The results of the study are supported by research conducted by Judge et al., (2014) namely the type of extraversion personality has a positive and significant influence on organizational citizenship behavior.

\section{Path Analysis}

Path analysis is an extension of multiple linear regression analysis to estimate the causality relationship between variables that have been predetermined based on theory (Ghozali, 2013). This study will examine the effect of perceived organizational support and extraversion personality on organizational citizenship behavior through affective commitment. To find out whether or not there is an effect of mediation, the following is the result of calculating the direct relationship, indirect relationship, and total indirect relationship between perceived organizational support, extraversion personality, affective commitment to organizational citizenship behavior. Firts, the path coefficient will 
be compared. The path coefficient is calculated by making two regression model equations. Following are the regression equations in this study:

Regression 1

$$
\begin{aligned}
& K A=b_{1} P D+b 2 K E+e 1 \\
& K A=0,206 P D+0,279 K E+092
\end{aligned}
$$

Regression 2

$$
\begin{aligned}
& \mathrm{PK}=\mathrm{b}_{1} \mathrm{PD}+\mathrm{b} 2 \mathrm{KE}+\mathrm{b} 3 \mathrm{KA}+\mathrm{e} 2 \\
& \mathrm{PK}=0,236 \mathrm{PD}+0,426 \mathrm{KE}+0,202 \mathrm{KA}+0,76
\end{aligned}
$$

Based on the results of the path analysis, it can be described the relationship of each variable through the image below:

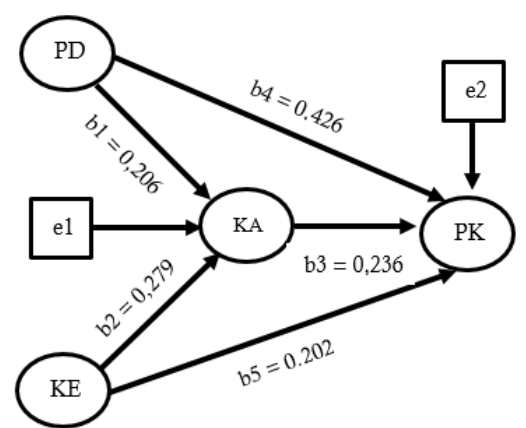

Figure 2. Path Analysis

Based on the results of the regression equation and path analysis above, the following table 3 is the result of calculating direct, indirect, and total indirect relationships between perceived organizational support, extraversion personality, and affective commitment to organizational citizenship behavior:

Table 3 shows that the direct effect of perceived organizational support on organizational citizenship behavior is 0.426 while the total effect is 0.475 . So it can be concluded that the total effect of the perception of organizational support through affective commitment $(0.475)>$ the direct effect of the perception of organizational support on organizational citizenship behavior (0.426), it can be concluded that the affective commitment in this study has a mediating effect even though it is only 0.049 . So H6 which states the perception of organizational support has a positive effect on organizational citizenship behavior through affective commitment is accepted.

The effect of perceived organizational support on organizational citizenship behavior will be even higher if it is balanced with affective commitment to Aneka Jaya Sambiroto Self-service employees. The results of the study are in line with research conducted by Gupta et al., (2016) that affective commitment is able to mediate the relationship between perceived organizational support and organizational citizenship behavior.

Based on the results of the study, Aneka Jaya Sambiroto Supermarket employees assume that management has provided support, one of which is to accommodate the aspirations of employees through a briefing session just before opening the store and closing the shop. So that it makes employees feel that all employees have an important role in the success of the store. Employees who have personal meanings will more easily show concern for the work environment, such as awareness of store cleanliness even though it is not the primary responsibility of employees.

The next path coefficient calculation is the effect of extraversion personality on organizational citizenship behavior through affective commitment of. The direct effect is 0,202 while the total direct effect is 0,268 . So that the total influence of the personality of extraversion on organizational citizenship behavior through affective commitment (0.268)> the direct influence of personality overversion on organizational citizenship behavior (0.202), it can be concluded that affective commitment has a mediating effect. That is, $\mathrm{H} 4$ which states extraversion personality positively influences organizational citizenship behavior through affective commitment is accepted.

The above research results are supported by research conducted by Purba et al. (2015) ie affective commitment is able to mediate the relationship between extraversion personality types

Table 3. Path Coefficient

\begin{tabular}{llllll}
\hline No & Variable & Influence & KA & PK & Total \\
\hline 1 & PD & Direct & & 0,426 & $\mathbf{0 , 4 2 6}$ \\
& & Indirect & 0,206 & 0,236 & $0,426 \times 0,236=0,049$ \\
\multicolumn{1}{l}{ Total } & & & & $0,426+0,049=0,475$ \\
\hline 2 & KE & Direct & & 0,202 & $\mathbf{0 , 2 0 2}$ \\
& Indirect & 0,279 & 0,236 & $0,279 \times 0,236=0,066$ \\
\multicolumn{2}{l}{ Total } & & & & $0,202+0,066=0,268$ \\
\hline
\end{tabular}


and organizational citizenship behavior. Based on the results of the study, Aneka Jaya Sambiroto Supermarkets employees are able to socialize easily with anyone. This creates a pleasant atmosphere in the work environment and employees feel comfortable in the work environment. This comfort encourages self-awareness in employees to maintain the facilities provided by the store management.

\section{CONCLUSION AND RECOMMENDATION}

The conclusion of this research is the perception of organizational support, personality extraversion, and affective commitment partially positive effect on organizational citizenship behavior. It has been proven that affective commitment can mediate the relationship between perceived organizational support and organizational citizenship behavior, but the effect is quite small, and vice versa. Affective commitment has also been proven to mediate the relationship between personality extraversion with organizational citizenship behavior but the effect is quite small. Employee organizational citizenship behavior is very beneficial for the company. Because employees will do their best for the success of the store. So from the results of this study, researchers suggested that the store management pay attention to the welfare of employees at work such as the construction of a place to rest for employees. If the employee feels comfortable, the employee will commit to the organization and not easily move from the workplace. In addition, researchers also suggest that store management conduct leadership training for employees who have received promotions and hold seminars or training on personality building in order to support their expertise in working specifically pramuaniaga who must meet with customers.

This study has limitations, namely the selection of objects that are not appropriate, because the conditions of employees who do not have enough work period to be able to explain or illustrate organizational support and commitment. Future research is expected to choose companies in the retail field that have employees with sufficient working years long. In addition, future research can develop other research variables that can influence organizational citizenship behavior such as organizational culture. Because in this millennial era, many store or company management makes organizational citizenship behavior an obligation and one of the building blocks of the organization's culture. Especially in the service sector, customer service is paramount and employees must be able to apply organizational culture but the main work of employees must still be completed.

\section{REFERENCES}

Afsar, B., \& Badir, Y. F. (2016). Organization Fit, Perceived Organizational Support, and Organizational Citizenship Behavior: the Role of Job Embeddedness. Journal of Human Resources in Hospitality \& Tourism, 15(3), 252-278.

Ahmed, I., Nawaz, M. M., Ali, G., \& Islam, T. (2015). Perceived Organizational Support and its Outcomes a Meta-Analysis of Latest Available Literature. Management Research Review, 38(6), 627-639.

Allen, N. J., \& Meyer, J. P. (1990). The Measurement and Antecedents of Affective, Continuance and Normative Commitment to the Organization. Journal of Occupational Psychology, 63(1), 1-18.

Ardi, R. T. B., \& Sudarma, K. (2015). Pengaruh Perssepsi Dukungan dan Keadilan Organisasi terhadap Organizational Citizenship Behavior dengan Komitmen Organisasional sebagai Variabel Intervening. Management Analysis Journal, 4(2), 142-152.

Aussy, W. N. A., \& Sudarma, K. (2017). Pengaruh Person Organization Fit dan Personality pada Organizational Citizenship Behavior dengan Organizational Commitment Sebagai Variabel Intervening. Management Analysis Journal, 6(3).

Barrick, M. R., \& Mount, M. K. (2005). Yes, Personality Matters : Moving on to More Important Matters. Human Performance, 18(4), 359-372.

Bolino, M. C., Klotz, A. C., Turnley, W. H., \& Harvey, J. (2013). Exploring the Dark Side of Organizational Citizenship Behavior. Journal of Organizational Behavior, 34, 542-559.

Brown, R.b. (1996) Organizational Commitment: Clarifying the Concepts and Simplifying the Existing Construct Typology. Journal of Vocational Behavior, 49(3), 230-251.

Chan, S. H. J., \& La, H. Y. I. (2016). Understanding The Link Between Communication Satisfaction, Perceived Justice and Organizational Citizenship behavior. Journal of Business Research.

Chiang, C., \& Hsieh, T. (2012). International Journal of Hospitality Management the Impacts of Perceived Organizational Support and Psychological Empowerment on Job Performance : the Mediating Effects of Organizational Citizenship Behavior. International Journal of Hospitality Management, 31(1), 180-190.

Dai, Y.-D., Hou, Y.-H., Chen, K.-Y., \& Zhuang, W.-L. (2016). To Help or Not to Help : Antecedents of Hotel Employees' Organizational Citizenship Behavior. International Journal of Contemporary Hospitality Management, 30(3), 1293-1313.

Elanain, H. A. (2007). Relationship between Personality and Organizational Citizenship Behavior: Does Personality Influence Employee Citizenship?. International Review of Business Research 
Papers, 3(4), 31-43.

Feather, N. T., \& Rauter, K. A. (2004). Organizational Citizenship Behaviours in Relation to Job Status, Job Insecurity, Organizational Commitment and Identification, Job Satisfaction and Work Values. Journal of Occupational and Organizational Psychology, 77, 81-94.

Ferdinand, A. 2014. Metode Penelitian Manajemen Pedoman Penelitian untuk Penulisan Skripsi, Tesis, dan Disertasi Ilmu Manajemen. Semarang: Undip Press.

Fitriastuti, T. (2013). Pengaruh Kecerdasan Emosional, Komitmen Organisasional dan Organizational Citizenship Behavior terhadap Kinerja Karyawan. Jurnal Dinamika Manajemen, 4(2), 103-114.

Ghozali, I. (2016). Aplikasi Analisis Multivariate dengan Program IBM SPSS 23 ( $7^{\text {th }}$ ed.). Semarang: Universitas Diponegoro.

Grant, A. M., Dutton, J. E., \& Rosso, B. D. (2008). Giving Commitment : Employee Support Programs and the Prosocial Sensemaking Process. Academy of Management Journal, 51(5), 898-918.

Griffin, M., Patterson, M., \& West, M. A. (2001). Job Satisfaction and Teamwork: The Role of Supervisor Support Job satisfaction and teamwork : the role of supervisor support. Journal of Organizational Behavior, 22, 537-550.

Gupta, V., Agarwal, U. A., \& Khatri, N. (2016). The Relationships between Perceived Organizational Support, Affective Commitment, Psychological Contract Breach, Organizational Citizenship Behavior, and Work Engagement. Journal of Advanced Nursing, 2806-2817.

Harrison, D. A., Newman, D. A., \& Roth, P. L. (2006). How Important Are Job Attitudes? Meta-Analytic Comparisons of Integrative Behavioral Outcomes and Time Sequences. Academy of Management Journal, 49, 305-325.

Hidayah, S. (2018). Role of Organizational Citizenship Behavior (OCB), Perception of Justice and Job Satisfaction on Employee Performance. Jurnal Dinamika Manajemen, 9(36), 170-178.

Hoon, H., \& Tan, T. M. L. (2008). Organizational Citizenship Behavior and Social Loafing: The Role of Personality, Motives, and Contextual Factors. The Journal of Psychology: Interdisciplinary and Applied, 142(1), 89-108.

Huang, C.-C., You, C.-S., \& Tsai, M.-T. (2012). A Multidimensional Analysis of Ethical Climate, Job Satisfaction, Organizational Commitment, and Organizational Citizenship Behaviors. Nursing Ethics, 19(4), 513-529.

Judge, T. A., Simon, L. S., \& Kelley, K. (2014). What I Experienced Yesterday Is Who I Am Today: Relationship of Work Motivations and Behaviors to Within-Individual Variation in the FiveFactor Model of Personality. Journal of Applied Psychology, 99(2), 199-221.

Knippenberg, D. Van, Prooijen, J. Van, \& Sleebos, E. (2015). Beyond Social Exchange: Collectivism's Moderating Role in the Relationship be- tween Perceived Organizational Support and Organizational Citizenship Behaviour. European Journal of Work and Organizational Psychology, 24(1), 152-160.

Krishnan, J., \& Mary, S. (2012). Perceived Organisational Support an Overview on its Antecedents and Consequences. International Journal of Multidisciplinary Research, 2(4).

Kurtessis, J. N., Eisenberger, R., Ford, M. T., \& Stewart, K. A. (2016). Perceived Organizational Support: A Meta-Analytic Evaluation of Organizational Support Theory. (March).

Lim, B. T. H., \& Loosemore, M. (2017). The Effect of Inter-Organizational Justice Perceptions on Organizational Citizenship Behaviors In Construction Projects. International Journal of Project Management, 35(2), 95-106.

Mahdiuon, R., Ghahramani, M., \& Rezaii, A. (2010). Explanation of Organizational Citizenship Behavior with Personality. Procedia Social and Behavioral Sciences, 5, 178-184.

Mangundjaya, W. L. H. (2012). Persepsi Dukungan Organisasi Versus Kepuasan Kerja Organisasi.

Martono, S., \& Putri, V. W. (2018). HRM Practices in Indonesia : the Contributing Power of Embeddedness and Support. Jurnal Dinamika Manajemen, 9(36), 206-217.

Mccrae, R. R., Costa, P. T., \& Martin, T. A. (2005). The NEO - PI - 3 : A More Readable Revised NEO Personality Inventory The. Journal of Personality Assessment, 84(3), 261-270.

Meyer, J. P., Stanley, D. J., Herscovitch, L., \& Topolnytsky, L. (2002). Affective, Continuance, and Normative Commitment to the Organization : A Meta-analysis of Antecedents, Correlates, and Consequences. Journal of Vocational Behavior, 61, 20-52.

Mosalaei, H., Nikbakhsh, R., \& Tojari, F. (2014). The Relationship between Personality Traits and Organizational Citizenship Behavior on Athletes. Bulletin of Environment, Pharmacology and Life Sciences, 3(1), 11-15.

Muhammad, A. H. (2014). Perceived Organizational Support and Organizational Citizenship Behavior: The Case of Kuwait. International Journal of Business Administration, 5(3), 59-72.

Mukhodah, \& Ranihusna, D. (2018). Organizational Commitment as Intervening Variable of Intrinsic and Extrinsic Motivation to Organizational Citizenship Behavior. International Conference on Economics, Business and Economic Education, 2018, 333-346.

Murphy, L., Eduljee, N. B., Croteau, K., \& Parkman, S. (2017). Extraversion and Introversion Personality Type and Preferred Teaching and Classroom Participation : A Pilot Study Extraversion and Introversion Personality Type and Preferred Teaching and Classroom Participation: A Pilot Study. Journal of Psychosocial Research, 12(2), 437-450.

Nisar, Q. A., Marwa, A., Ahmad, U., \& Ahmad, S. (2014). Impact of Perceived Organizational 
Support on Organizational Citizenship Behavior: Empirical Evidence from Pakistan. International Journal of Research, 1(5), 231-240.

Novira, L., \& Martono, S. (2015). Pengaruh Persepsi Dukungan Organisasi pada Perilaku Kewargaan Organsasional dengan Kepuasan Kerja sebagai Variabel Intervening. Management Analysis Journal, 4(3), 180-189.

Nurlaila, F., \& Sudarma, K. (2017). Pengaruh Tuntutan Pekerjaan, Tipe Kepribadian Ekstrovert, dan Dukungan Supervisor pada Kelelahan Emosional. Management Analysis Journal, 6(4).

Organ, D. W., \& Lingl, A. (1995). Personality, Satisfaction, and Organizational Citizenship Behavior. The Journal of Social Psychology, 135(3), 339-350.

Oussama, S., \& Johari, H. (2016). The Mediating Effect of Organizational Citizenship Behavior on the Relationship between Perceived Organizational Support and Turnover Intention: A Proposed Framework. International Review of Management and Marketing, 6, 345-354.

Panaccio, A., \& Vandenberghe, C. (2012). Five-Factor Model of Personality and Organizational Commitment : The Mediating Role of Positive and Negative Affective States. Journal of Vocational Behavior, 80(3), 647-658.

Podsakoff, N. P., Whiting, S. W., Podsakoff, P. M., \& Blume, B. D. (2009). Individual- and Organizational-Level Consequences of Organizational Citizenship Behaviors : A Meta-Analysis. Journal of Applied Psychology, 94(1), 122-141.

Pradhan, R. K., \& Jena, L. K. (2016). Effect of WorkLife Balance on Organizational Citizenship Behaviour: Role of Organizational Commitment. (June).

Purba, D. E., Oostrom, J. K., Molen, H. T. Van Der, \& Born, M. P. (2014). Personality and Organizational Citizenship Behavior in Indonesia : The Mediating Effect of Affective Commitment.
Asian Business \& Management, 1-24.

Ramdhani, N. (2007). Apakah Kepribadian Menentukan Pemilihan Media Komunikasi? Metaanalisis terhadap Hubungan Kepribadian Extraversion, Neuroticism, dan Openness to Experience dengan Penggunaan Email. Jurnal Psikologi, 34(2), 112-129.

Revelle, W. (2016). Hans Eysenck : Personality Theorist. Personality and Individual Differences, 103, 32-39.

Sena, T. F. (2011). Variabel Antiseden Organizational Citizenship Behavior (OCB). Jurnal Dinamika Manajemen, 2(1), 70-77.

Somech, A., \& Zahavy, A. D. (2013). Organizational Citizenship Behaviour and Employee's Strain: Examining the Buffering Effects of Leader Support and Participation in Decision Making. European Journal of Work and Organizational Psychology, 22(2), 138-149.

Tahapary, J. F., \& Martono, S. (2017). Pengaruh Budaya Organisasi, Stres Kerja dan Komitmen Afektif terhadap Keinginan Keluar. Management Analysis Journal, 6(1).

Turnipseed, D. L., \& Rassuli, A. (2005). Performance Perceptions of Organizational Citizenship Behaviours at Work: a Bi-Level Study among Managers and Employees. British Journal of Management, 16, 231-244.

Udiyana, I. B. G., Wignjohartoyo, P., \& Sulasmi, S. (2015). Mama Model Approach: Its Implication to Commitment and Organizational Citizenship Behavior. Jurnal Dinamika Manajemen, 6(17), 153-162.

Zheng, J., \& Wu, G. (2018). Work-Family Conflict, Perceived Organizational Support and Professional Commitment : A Mediation Mechanism for Chinese Project Professionals. International Journal of Environmental Research and Public Health, 15. 